Raf. J. Sci.,Vol.28, No.2 Special Issue for the Third Scientific Conference of Chemistry, pp.64-75, 2019

\title{
Electrochemical Behavior of Valsartan, Glibenclamide and their Interaction with Each other Using Square Wave Voltammetry
}

\author{
*Aws Z. Al-Hafidh \\ Amer Th. Al-Taee \\ Department of Chemistry/ College of Science/ University of Mosul \\ *E-mail: Aws.alhafidh@gmail.com*
}

(Received 20/8/2018;Accepted 25/10/2018)

\begin{abstract}
In this work an electrochemical behavior quantification and interaction of valsartan and glibenclamide were studied using square wave voltammetric technique. The effect of temperature on the interaction was investigated and the thermodynamic parameters $(\Delta H, \Delta S \& \Delta G)$ were calculated for the interaction and binding constant $(\mathrm{K})$ also obtained. The calibration curves of each drug were linear within the range of concentration $\left[\left(4.99 \times 10^{-7}\right)-\left(6.95 \times 10^{-6}\right)\right],\left[\left(5.96 \times 10^{-8}\right)-\right.$ $\left(1.15 \times 10^{-6}\right)$ ] molar with $\mathrm{R}^{2}$ value equal to 0.9819 , 0.9926 for valsartan and glibenclamide respectively.
\end{abstract}

Keywords: Square wave voltammetry (SWV), Valsartan, Glibenclamide, Drug interaction.

\section{اللسلوك الكهروكيميائي الفالسارتلن، الغليبنكلميد وتدالخلهمامع بهضهما البضن بلستخدلمفولتامتري

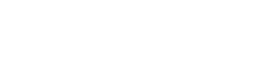

\section{الملغص}

في هذا البهث مُ درلسة اللسلوك الكمي الكهروكيميائي والتدلخل لفللسارتلن والغليبنكلاميد بلستخدلم ققني ـة فولت المتري

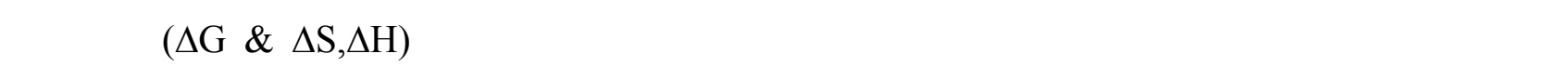




على التوالمي.

الهاملت الدالة: فولتلمتري الموجة المربعة، الفللسارتلن، الغليبنكلاميد، تدلخل دوائي.

\section{INTRODUCTION}

Valsartan N-((2'-(1H-tetrazol-5-yl)-[1,1'-biphenyl]-4-yl)methyl)-N-pentanoylvaline Fig. (1), is a new orally active of antihypertensive drug belonging to the family of angiotensin II receptor antagonists acting at the ATI receptor, which mediates all known effects of angiotensin II on the cardiovascular system (Nie et al., 2005). Valsartan is widely used in the treatment of hypertension (Iriarte et al., 2007). Therefore, an analytical method for the determination of unchanged valsartan with high accuracy is of great importance. 


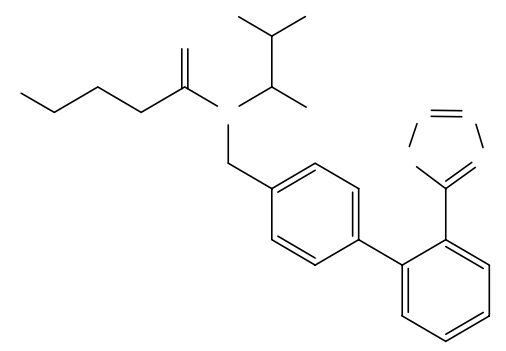

Fig. 1: Valsartan

Several methods for the determination of valsartan in pharmaceutical dosageaforms have been reported in literature including high performance liquid chromatography (HPLC) with a fluorescence detector (FP) (Iriarte et al., 2007; Macek et al., 2006), liquid chromatography-tandem mass spectrometry (Koseki et al., 2007), and spectrophotometry (Tatar and Saglik, 2002). So far, there are few electrochemical methods for the determination of valsartan, either in pharmaceutical dosage forms or in bulk form (Yan et al., 2008 ; Ramadan et al., 2012 ; Habib et al., 2007).

Glibenclamide Fig. (2), (1-p-[2-(5-chloro-o-anisamido)ethyl[phenyl]-sulfonyl]-3-cyclohexyl urea ; glyburide) is a potent, second generation oral sulfonylurea antidiabetic agent widely-used to lower blood glucose levels in patients with type II non-insulin-dependent diabetes mellitus. It acts mainly by stimulating endogenous insulin release from beta cells of the pancreas (Radi, 2004). Glibenclamide is rapidly and completely absorbed from the gastrointestinal tract. Different methods have been used for the determination of glibenclamide among these methods, different HPLC methods coupled with UV detection (Porwal and Talele, 2017) fluorescence detection (Khatri et al., 2001), or mass spectrometry (Ramos et al., 2000).

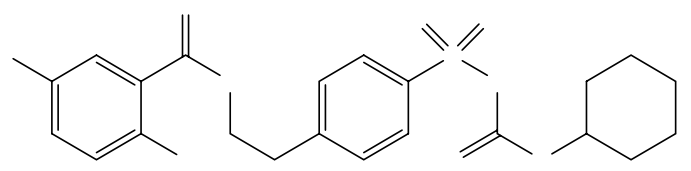

Fig. 2: Glibenclamide

A drug interaction is a situation in certain medicines can interact pharmacologically and affect the activity of other medicines. This action can be synergistic (when the drug's effect is increased) or antagonistic (when the drug's effect is decreased). These interactions may occur out of accidental misuse or due to lack of knowledge about the active ingredients involved in the relevant substances (Mohapatra et al., 2018). It is therefore easy to see the importance of these pharmacological interactions in the practice of medicine, if a patient is taking two drugs and one of them increases the effect of the other it is possible that an overdose may occur. The interaction of the two drugs may also increase the risk that side effects will occur. On the other hand, if the action of a drug is reduced, it may cease to have any therapeutic use because of under dosage (Alfonso and Gayo, 2005). The SWV also used for study the interaction of different biological compounds and drugs with albumin (Sulaiman and Bader, 2009 ; Sulaiman and Al-Imam, 2012).

In this work, an electrochemical behaviour of valsartan and glibenclamide were investigated, also their interaction with each other was examined for this purpose a simple, rapid and sensitive square wave voltammetric (SWV) technique was developed. The developed method was applied to determine the valsartan and glibenclamide in pharmaceutical formulations. 


\section{EXPERIMENTAL}

\section{Apparatus}

SWVs were performed using a 797 VA Computrace supplied by Metrohm, Switzerland, coupled with a three-electrode detection system and consists of hanging mercury drop electrode ( $\mathrm{HMDE}$ ), an $\mathrm{Ag} / \mathrm{AgCl} / \mathrm{sat}$. $\mathrm{KCl}$ as reference electrode and $1 \mathrm{~mm}$ platinum wire was used as an auxiliary electrode.

$\mathrm{pH}$ measurements were performed using a digital $\mathrm{pH}$ meter supplied by HANNA company, Portugal, model $\mathrm{pH} 211$, microprocessor $\mathrm{pH}$ meter with accurate to \pm 0.05 .

HAAKE G supplied by HAAKE company, Germany, water bath was used for controlling temperature during the measurements.

\section{Reagents and Procedure}

All chemicals used were all analytical grade (Fluka, BDH). The valsartan and glibenclamide were kindly supplied by Sammira drugs industry. Stock solutions of each drug were prepared by dissolving an appropriate amount of valsartan and glibenclamide in absolute ethanol and dimethyl formamide (DMF), respectively. The supporting electrolyte was phosphate buffer $\left(\mathrm{K}_{2} \mathrm{HPO}_{4}\right.$ and $\mathrm{KH}_{2} \mathrm{PO}_{4}$ ).

The buffer solution was placed in polarographic cell and deoxygenated via purging with $\mathrm{N}_{2}$ gas for $5 \mathrm{~min}$ prior the measurements. After recording the buffer voltammogram, the test solution added to the polarographic cell and the square wave voltammograms were recorded under the optimum conditions for a sequence additions of standard stock solutions of each drug, then the calibration curve was constructed for each drug.

\section{Electrochemical Behavior of Valsartan}

\section{RESULTS AND DISCUTION}

SWV of valsartan shows a well-defined reduction peak at $(-1.07) \mathrm{V}$ versus $\mathrm{Ag} / \mathrm{AgCl} / \mathrm{sat} . \mathrm{KCl}$ under the default conditions of instrument in phosphate buffer $(\mathrm{pH}=7)$.

\section{Optimum Condition for Valsartan}

In order to optimize the conditions for measurements, various instrumental and experimental variables such as frequency, scan increment, pulse amplitude, supporting electrolyte and $\mathrm{pH}$ were examined and optimized, using $9.9 \times 10^{-5} \mathrm{M}$ valsartan in phosphate buffer as supporting electrolyte, the results obtained are shown in (Table 1).

Table 1: The optimum condition for $9.9 \times 10^{-5} \mathrm{M}$ valsartan in phosphate buffer $(\mathrm{pH}=6)$

\begin{tabular}{|c|c|}
\hline Start Potential (V) & -1.5 \\
\hline End Potential (V) & -0.5 \\
\hline Deposition potential (V) & -0.6 \\
\hline Deposition time (s) & 30 \\
\hline Equilibration time (s) & 1 \\
\hline Voltage step (V) & 0.006 \\
\hline Amplitude (V) & 0.06 \\
\hline Frequency (Hz) & 50 \\
\hline Drop size & 4 \\
\hline Sweep rate (V/s) & 0.3 \\
\hline
\end{tabular}

The square wave voltammograms were recorded for $4.97 \times 10^{-5} \mathrm{M}$ valsartan in phosphate buffer at different $\mathrm{pHs}$, by adding appropriate amount of $\mathrm{K}_{2} \mathrm{HPO}_{4}$ and $\mathrm{KH}_{2} \mathrm{PO}_{4}$. It can be seen from Fig.(3), the reduction peak current, peak shape and peak potential depended strongly on $\mathrm{pH}$. The optimum $\mathrm{pH}$ was found to be $\mathrm{pH}=6$, which is used for determination, where as $\mathrm{pH}=7$ (human blood $\mathrm{pH})$ was used for interaction studies. 


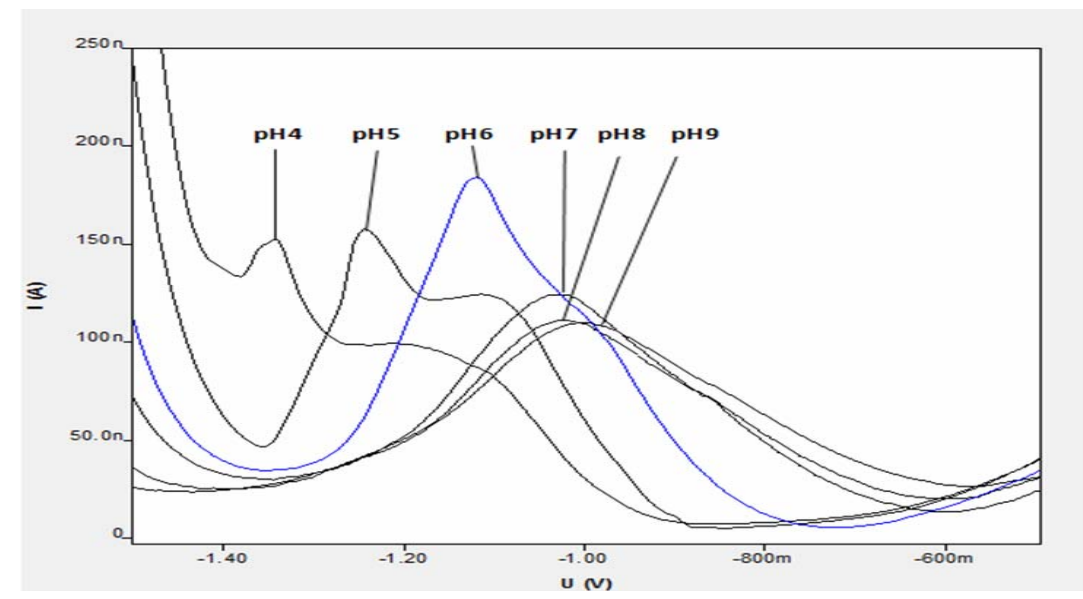

Fig. 3: Effect of $\mathrm{pH}$ on the reduction peak current of valsartan $\left(4.97 \times 10^{-5} \mathrm{M}\right)$

\section{Stability of Reduction Peak}

To study the stability of reduction peak of valsartan a voltammogram of $9 \times 10^{-5} \mathrm{M}$ valsartan was recorded under the mentioned optimum conditions (Table 1) versus time. The results obtained are shown in (Table 2), it is clear that the reduction peak current is stable within the time studied.

\section{Table 2: Stability of reduction peak current of $9 \times 10^{-5} \mathrm{M}$ valsartan in $\mathrm{pH6}$}

\begin{tabular}{|c|c|c|}
\hline Time (min) & Ip of VAL (nA) & Ep of VAL (V) \\
\hline 0 & 284 & -1.08 \\
\hline 5 & 287 & -1.08 \\
\hline 10 & 278 & -1.08 \\
\hline 15 & 278 & -1.08 \\
\hline 20 & 291 & -1.08 \\
\hline 25 & 291 & -1.08 \\
\hline 30 & 296 & -1.08 \\
\hline 35 & 276 & -1.08 \\
\hline 40 & 275 & -1.08 \\
\hline 45 & 278 & -1.08 \\
\hline 50 & 277 & -1.08 \\
\hline 55 & 279 & -1.08 \\
\hline 60 & 280 & -1.08 \\
\hline
\end{tabular}

\section{Calibration Curve of Valsartan}

The calibration curve was constructed by adding a sequence addition of standard valsartan solution $\left(10^{-3} \mathrm{M}\right)$ and the voltammogram was recorded for each addition Fig. (4) under the previous optimum conditions (Table 1). The plot of peak current versus concentration Fig. (5) gives a straight line with $\mathrm{R}^{2}=0.9819$ and concentration range $\left[\left(4.99 \times 10^{-7} \mathrm{M}\right)-\left(6.95 \times 10^{-6} \mathrm{M}\right)\right]$. 


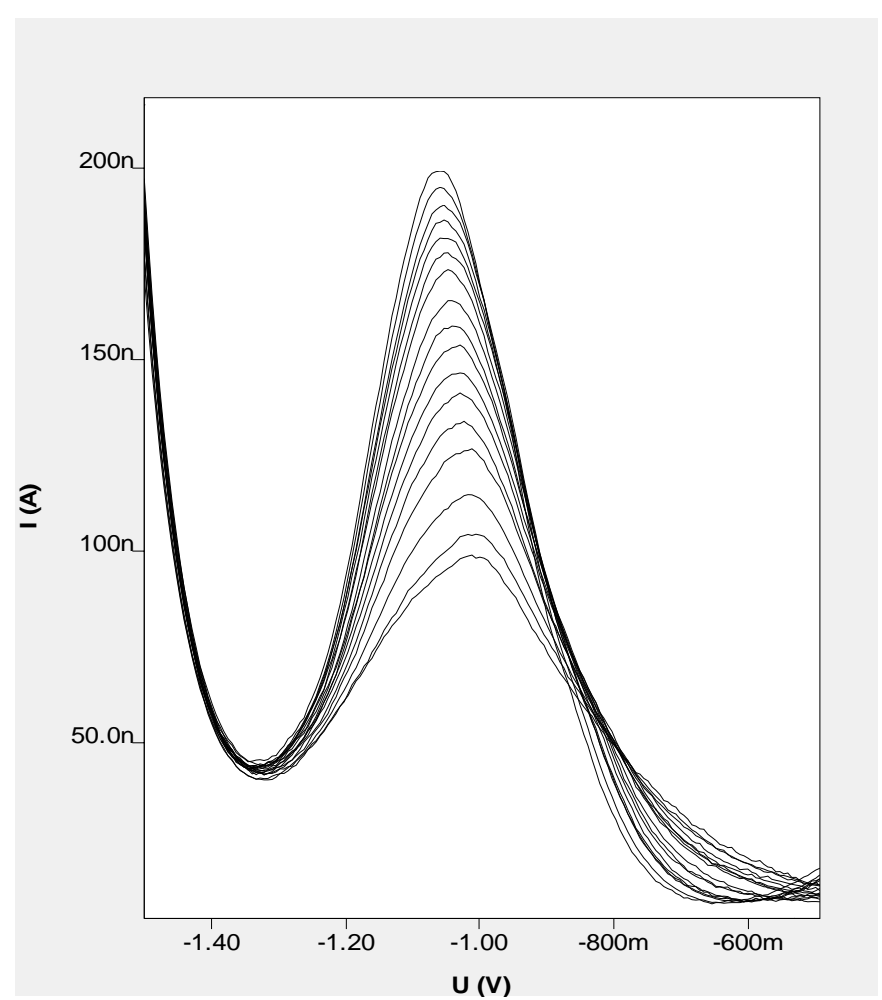

Fig. 4: Voltammograms of sequence addition of standard valsartan solution $\left(10^{-3} \mathrm{M}\right)$ in phosphate buffer $(\mathrm{pH}=6)$

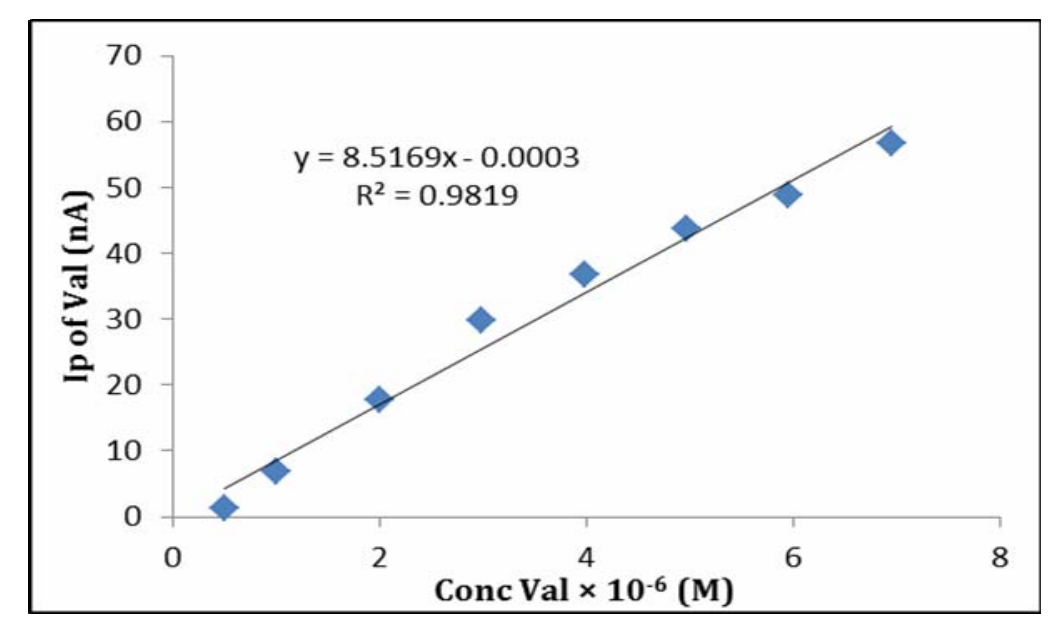

Fig. 5: The calibration curve of valsartan using phosphate buffer $(\mathrm{pH}=6)$

\section{Electrochemical Behavior of Glibenclamide}

SWV of glibenclamide shows a well-defined reduction peak at (-1.37) V versus $\mathrm{Ag} / \mathrm{AgCl} / \mathrm{sat}$. $\mathrm{KCl}$ under the default conditions of instrument in phosphate buffer $(\mathrm{pH}=7)$.

\section{Optimum Condition for Glibenclamide}

In order to optimize the conditions for measurements, various instrumental and experimental variables such as frequency, scan increment, pulse amplitude, supporting electrolyte and $\mathrm{pH}$ were examined and optimized, using $1.96 \times 10^{-5} \mathrm{M}$ glibenclamide in phosphate buffer as supporting electrolyte. The results obtained are shown in (Table 3). 
Table 3: The optimum condition for $1.96 \times 10^{-5} \mathrm{M}$ glibenclamide in phosphate buffer $(\mathrm{pH}=8)$

\begin{tabular}{|c|c|}
\hline Start Potential (V) & -1.6 \\
\hline End Potential (V) & -0.8 \\
\hline Deposition potential (V) & -0.6 \\
\hline Deposition time (s) & 30 \\
\hline Equilibration time (s) & 1 \\
\hline Voltage step (V) & 0.016 \\
\hline Amplitude (V) & 0.06 \\
\hline Frequency (Hz) & 50 \\
\hline Drop size & 4 \\
\hline Sweep rate (V/s) & 0.3 \\
\hline
\end{tabular}

The square wave voltammograms were recorded for $1.2 \times 10^{-4} \mathrm{M}$ glibenclamide in phosphate buffer at different pHs. It can be seen from Fig. (6), the reduction peak current, peak shape and peak potential depend strongly on $\mathrm{pH}$. the optimum $\mathrm{pH}$ was found to be $\mathrm{pH}=8$.

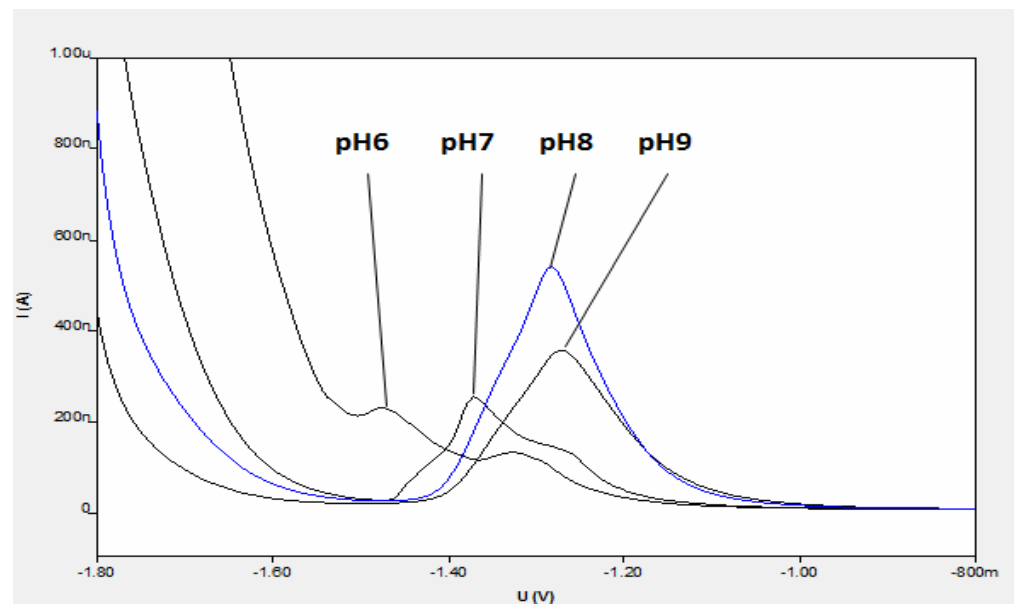

Fig. 6: Effect of $\mathrm{pH}$ on the reduction peak current of glibenclamide $\left(1.2 \times 10^{-4} \mathrm{M}\right)$

\section{Stability of reduction peak}

To study the stability of reduction peak of glibenclamide, a voltammogram of $1.96 \times 10^{-5} \mathrm{M}$ glibenclamide was recorded under the mentioned optimum conditions (Table 3) versus time. The results obtained are shown in (Table 4). It is clear that the reduction peak current is stable within the time studied.

Table 4: Stability of reduction peak of $1.96 \times 10^{-5} \mathrm{M}$ glibenclamide in $\mathrm{pH8}$

\begin{tabular}{|c|c|c|}
\hline Time (min) & Ip of GLB (nA) & Ep of GLB (V) \\
\hline 0 & 226 & -1.25 \\
\hline 5 & 217 & -1.26 \\
\hline 10 & 233 & -1.25 \\
\hline 15 & 213 & -1.26 \\
\hline 20 & 214 & -1.26 \\
\hline 25 & 217 & -1.26 \\
\hline 30 & 209 & -1.26 \\
\hline 35 & 227 & -1.26 \\
\hline 40 & 220 & -1.26 \\
\hline 45 & 211 & -1.26 \\
\hline 50 & 214 & -1.26 \\
\hline 55 & 215 & -1.26 \\
\hline 60 & 210 & -1.26 \\
\hline
\end{tabular}


The Calibration Curve of Glibenclamide

The calibration curve was constructed by adding a sequence addition of standard glibenclamide solution $\left(10^{-5} \mathrm{M}\right)$ and the voltammogram was recorded for each addition Fig. (7) under the previous optimum conditions (Table 3). The plot of peak current versus concentration Fig. (8) gives a straight line with $\mathrm{R}^{2}=0.9926$ and concentration range $\left[\left(5.96 \times 10^{-8} \mathrm{M}\right)-\right.$ $\left.\left(1.15 \times 10^{-6} \mathrm{M}\right)\right]$.

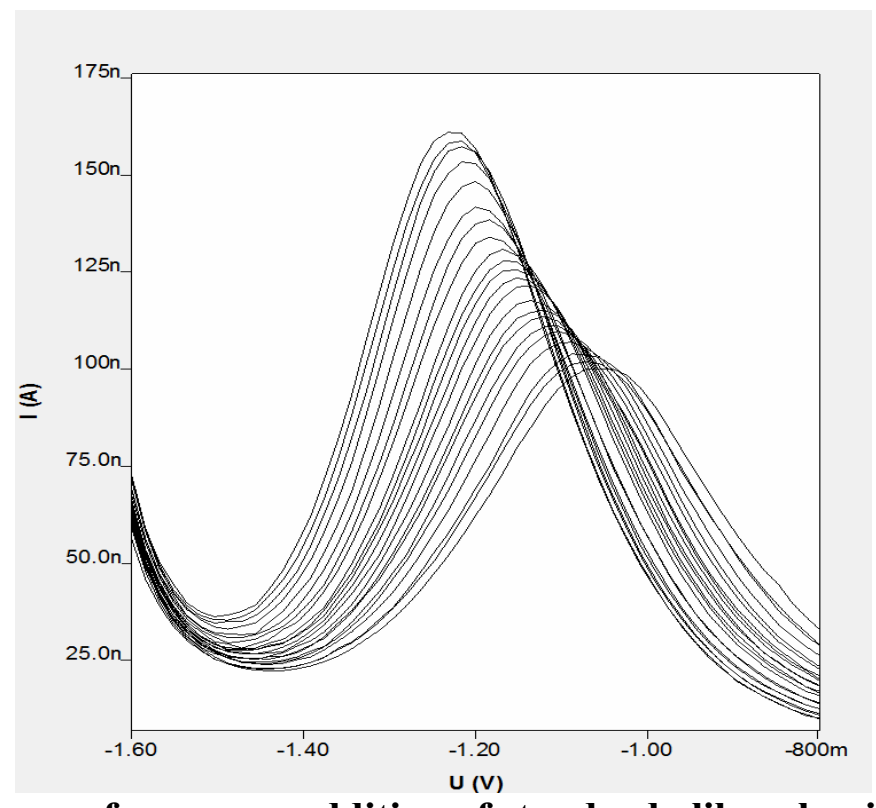

Fig. 7: Voltammograms of sequence addition of standard glibenclamide solution $\left(10^{-5} \mathrm{M}\right)$ in phosphate buffer $(\mathrm{pH}=8)$

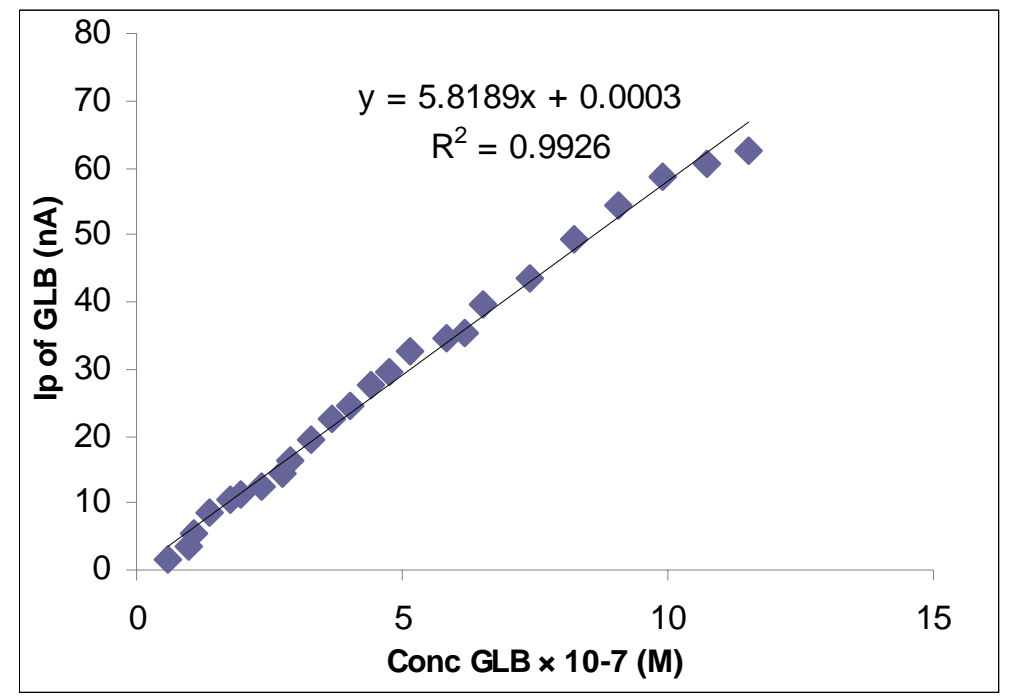

Fig. 8: The calibration curve of glibenclamide using phosphate buffer $(\mathrm{pH}=8)$

\section{Interactions of Valsartan with Glibenclamide}

Square wave voltammograms of $1.4 \times 10^{-5} \mathrm{M}$ valsartan were recorded under the optimum conditions (Table 1) for a sequence additions of glibenclamide solution at different temperatures using phosphate buffer $\mathrm{pH}=7$ (human blood $\mathrm{pH}$ ).

\section{Stability of Interaction}

To study the stability of interaction peak, a voltammogram of $1.9 \times 10^{-4} \mathrm{M}$ valsartan with $1.9 \times 10^{-7} \mathrm{M}$ glibenclamide was recorded under the mentioned optimum conditions of valsartan (Table 1) in phosphate buffer $\mathrm{pH}=7$ versus time. The results obtained are shown in (Table 5). It is clear that the interaction reduction peak current is stable within the time studied. 
Table 5: Stability of interaction reduction peak current $\left(1.9 \times 10^{-4} \mathrm{M}\right.$ valsartan with $1.9 \times 10^{-7} \mathrm{M}$ glibenclamide) using phosphate buffer $\mathrm{pH}=7$

\begin{tabular}{|c|c|c|}
\hline Time (min) & Ip of Interaction (nA) & Ep of Interaction (V) \\
\hline 0 & 236 & -1.03 \\
\hline 5 & 232 & -1.03 \\
\hline 10 & 227 & -1.03 \\
\hline 15 & 227 & -1.03 \\
\hline 20 & 226 & -1.04 \\
\hline 25 & 225 & -1.03 \\
\hline 30 & 225 & -1.03 \\
\hline 35 & 228 & -1.03 \\
\hline 40 & 231 & -1.03 \\
\hline 45 & 223 & -1.03 \\
\hline 50 & 221 & -1.03 \\
\hline 55 & 232 & -1.04 \\
\hline 60 & 222 & -1.04 \\
\hline
\end{tabular}

\section{Binding Constant}

The decrease in peak current of valsartan with a sequence additions of glibenclamide Fig. (9) at all studied temperatures were noticed. The relations between reduction peak current and glibenclamide concentrations added were linear at all studied temperatures with $\mathrm{R}^{2}$ equal to 0.9936 , $0.9867,0.9953,0.9795$ and 0.9922 for $288^{\circ}, 293^{\circ}, 298^{\circ}, 303^{\circ}$ and $310^{\circ} \mathrm{K}$ respectively. Thermodynamic parameters and binding constants were calculated (Table 6) according to equation (1) (Jalali and Dorraji, 2012) as shown in Figs. (10-14).

$$
\ln \left(\frac{I p}{I p^{\circ}-I \mathrm{p}}\right)=\ln \left(\frac{1}{[G L B]}\right)-\ln K_{\ldots . .}(1)
$$

where $\mathrm{K}$ is the binding constant, $\mathrm{Ip}^{\circ}$ and $\mathrm{Ip}$ are the reduction peak currents of the free valsartan and VAL- Glibenclamide complex, respectively. The plot of $\ln \left(\operatorname{Ip} /\left(\operatorname{Ip}^{\circ}-\mathrm{Ip}\right)\right)$ versus $\ln (1 /[\mathrm{GLB}])$ is $\operatorname{linear}$ and the binding constant was obtained from its intercept.



Fig. 9: The reduction peak of valsartan (a) with the sequence additions of glibenclamide (b) at $\left(298^{\circ} \mathrm{K}\right)$ 


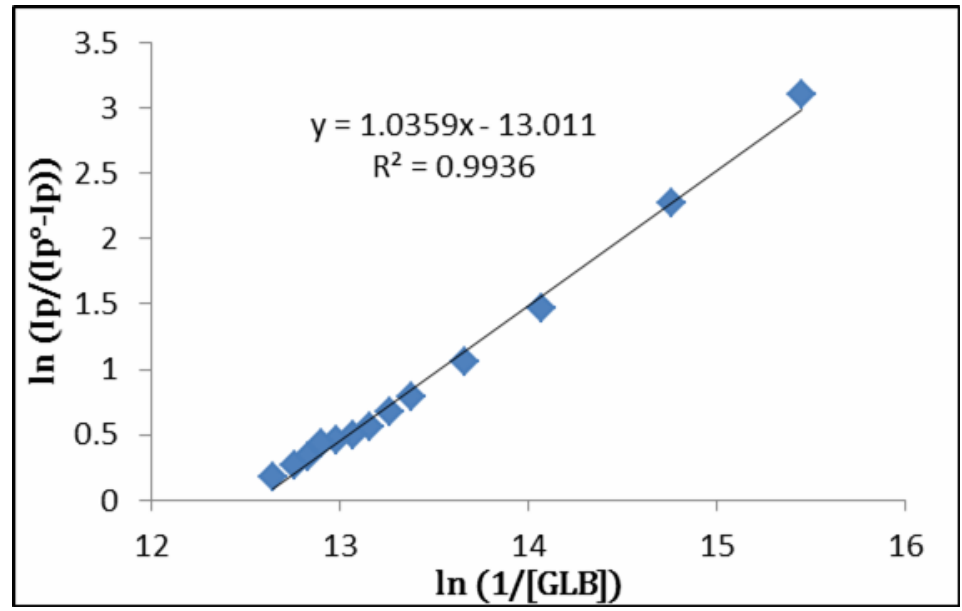

Fig. 10: Plot of $\ln \left(\mathrm{Ip} /\left(\mathrm{Ip}^{\circ}-\mathrm{Ip}\right)\right)$ vs $\ln (1 /[\mathrm{GLB}])$ at $288^{\circ} \mathrm{K}$



Fig. 11: Plot of $\ln \left(\mathrm{Ip} /\left(\mathrm{Ip}^{\circ}-\mathrm{Ip}\right)\right)$ vs $\ln (1 /[\mathrm{GLB}])$ at $293^{\circ} \mathrm{K}$

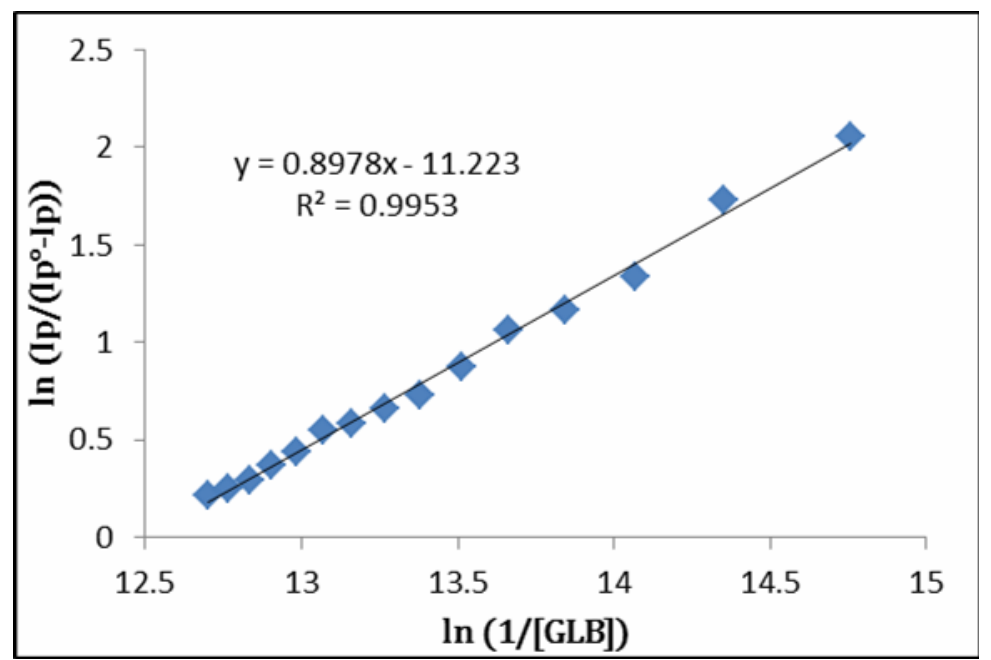

Fig. 12: Plot of $\ln \left(\mathrm{Ip} /\left(\mathrm{Ip}^{\circ}-\mathrm{Ip}\right)\right)$ vs $\ln (1 /[\mathrm{GLB}])$ at $298^{\circ} \mathrm{K}$ 


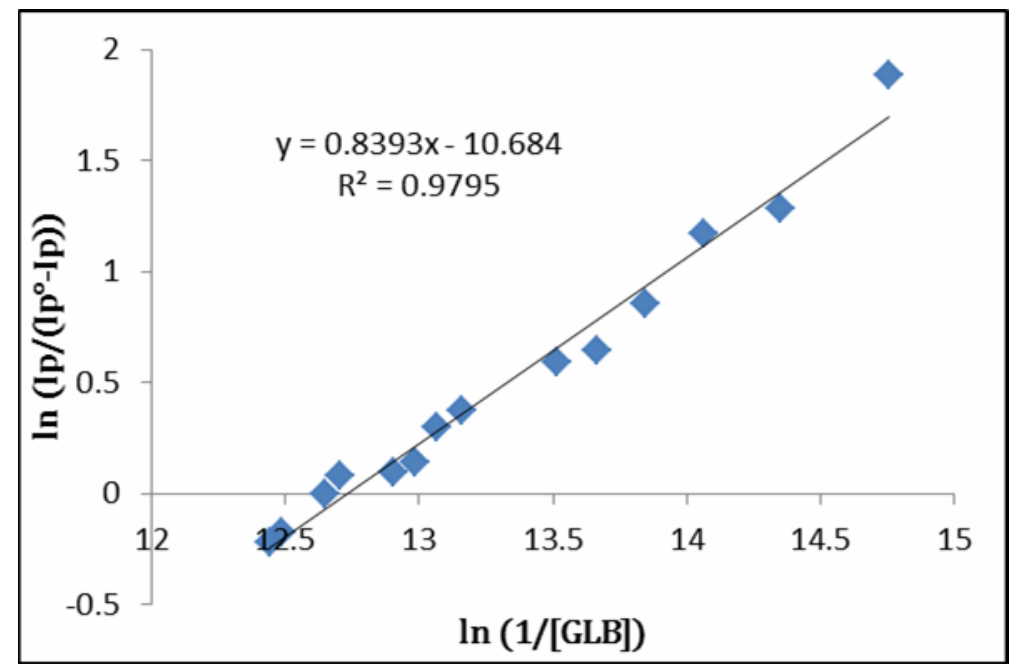

Fig. 13: Plot of $\ln \left(\mathrm{Ip} /\left(\mathrm{Ip}^{\mathrm{o}}-\mathrm{Ip}\right)\right)$ vs $\ln (1 /[\mathrm{GLB}])$ at $303^{\circ} \mathrm{K}$



Fig. 14: Plot of $\ln \left(\mathrm{Ip} /\left(\mathrm{Ip}^{\circ}-\mathrm{Ip}\right)\right)$ vs $\ln (1 /[\mathrm{GLB}])$ at $310^{\circ} \mathrm{K}$

\section{Thermodynamic parameters}

The plotting of ln K against 1/T using Van't Hoff equation (2), gives linear relationship Fig. (15). The change enthalpy $(\Delta \mathrm{H})$ was obtained from the slope, and other thermodynamics parameters $(\Delta \mathrm{G}$ and $\Delta \mathrm{S})$ were calculated (Table 6) as follow:

$$
\ln K=-\frac{\Delta \mathrm{H}}{\mathrm{RT}}+\frac{\Delta \mathrm{S}}{\mathrm{R}} \ldots
$$

Enthalpy $(\Delta \mathrm{H})$ was calculated from the slope (Equation 3)

$$
\Delta \mathrm{H}=- \text { Slope } \times \mathrm{R}
$$

$$
\left(\mathrm{R}=8.314 \mathrm{~J} . \mathrm{mole}^{-1} \cdot \mathrm{K}^{-1}\right)
$$

The free energy $(\Delta \mathrm{G})$ was calculated from the equation (4) of Van't Hoff described below:

$$
\Delta \mathrm{G}=-\mathrm{R} \times \mathrm{T} \times \ln \mathrm{K}
$$

Entropy $(\Delta S)$ was calculated from the intercept (Equation 5)

$$
\Delta \mathrm{S}=\text { Intercept } \times \mathrm{R}
$$

The plot of $\ln \mathrm{K}$ versus $1 / \mathrm{T}$ gives straight line with $\mathrm{R}^{2}$ equal to 0.9853 Fig. (18). 


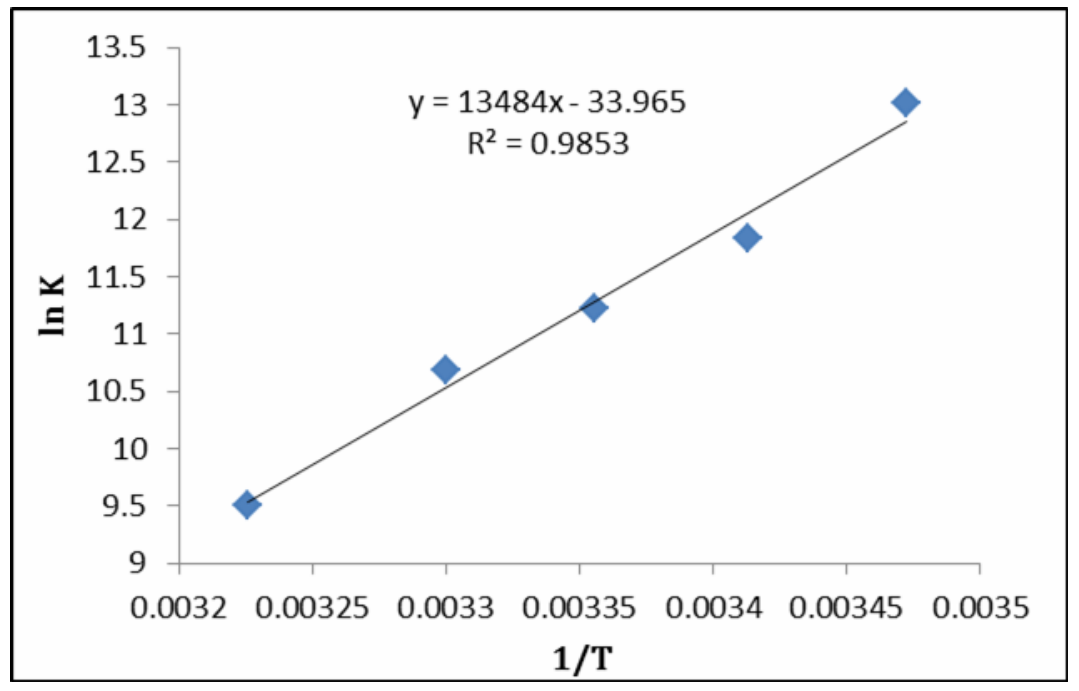

Fig. 15: Plot of In $\mathrm{K}$ versus 1/T of interaction between valsartan and glibenclamide

Table 6: Thermodynamics parameters and binding constants for valsartan and glibenclamide interaction

\begin{tabular}{|c|c|c|c|c|}
\hline $\begin{array}{c}\text { Temp } \\
\text { (K) }\end{array}$ & $\begin{array}{c}\text { Binding constant } \\
\left(\mathbf{K}_{\mathrm{b}}\right) \times \mathbf{1 0}^{4} \mathbf{M}^{-1}\end{array}$ & $\begin{array}{c}\Delta \mathbf{H} \\
\left(\mathrm{KJ}^{\prime} \mathrm{mol}^{-1}\right)\end{array}$ & $\begin{array}{c}\Delta \mathbf{G} \\
\left(\mathrm{KJ}^{\prime} \mathrm{mol}^{-1}\right)\end{array}$ & $\begin{array}{c}\Delta \mathbf{S} \\
\left(\mathrm{J} . m o l^{-1} \cdot \mathbf{K}^{-1}\right)\end{array}$ \\
\hline 288 & 44.7306 & \multirow{5}{*}{-112.1059} & -31.1539 & \multirow{5}{*}{-282.3850} \\
\hline 293 & 13.7723 & & -28.8252 & \\
\hline 298 & 7.4831 & & -27.8057 & \\
\hline 303 & 4.3651 & & -26.9145 & \\
\hline 310 & 1.3511 & & -24.5138 & \\
\hline
\end{tabular}

The negative value of $\Delta \mathrm{H}$ indicates that the binding interaction is exothermic and binding constant decrease with increasing temperature. Also $\Delta \mathrm{G}$ becomes more positive with increasing temperature means the spontaneously of binding decreased, where as the negative value of $\Delta \mathrm{S}$ indicates that which the system that became more ordered. The negative $\Delta \mathrm{H}$ and $\Delta \mathrm{S}$ values for the interaction of valsartan and glibenclamide indicate that the binding is mainly enthalpy and entropy driven, and the interaction may involve hydrogen bonding and van der Waals forces played a major role in the interaction (Ross and Subramanian, 1981).

\section{REFERENCES}

Alfonso, M.S.F.; Gayo, M.R. (2005). "Fundamentos De Farmacología Básica y Clínica". Published by Steve Bob Billy Joe. Spain. 232 p.

Habib, I.H.I.; Weshahy, S.A.; Toubar, S.S.; El-Alamin, M.M.A. (2007). Stripping voltammetric determination of valsartan in bulk and pharmaceutical products. Pharmazie., 63, 337-341.

Iriarte, G.; Ferreiros, N.; Ibarrondo, I.; Alonso, R.M.; Maguregui, M.I.; Jimenez, R.M. (2007). Biovalidation of an SPE-HPLC-UV-fluorescence method for the determination of valsartan and its metabolite valeryl-4-hydroxy-valsartan in human plasma. J. Sep. Sci., 30, 2231.

Jalali, F.; Dorraji, P.S. (2012). Electrochemical and spectroscopic studies of the interaction between the neuroleptic drug, gabapentin, and DNA. J. Pharm. and Biomed. Anal., 70, 598-601.

Khatri, J.; Qassim, S.; Abed, O.; Abraham, B.; Al-Lami, A.; Masood, S. (2001). A novel extractionless hplc fluorescence method for the determination of glyburide in the human plasma: application to a bioequivalence study. J. Pharm. Sci., 4(2), 201-206.

Koseki, N.; Kawashita, H.; Hara, H.; Niina, M.; Tanaka, M.; Kawai, R.; Nagae, Y.; Masuda, N. (2007). Development and validation of a method for quantitative determination of 
valsartan in human plasma by liquid chromatography-tandem mass spectrometry. $J$. Pharm. Biomed. Anal., 43, 1769.

Macek, J.; Klima, J.; Ptacek, P. (2006). Rapid determination of valsartan in human plasma by protein precipitation and high-performance liquid chromatography. J. Chromatogr. B, 832, 169.

Mohapatra, S.S.; Kafle, A.; Reddy, I.; Sarma, J. (2018). Drug interactions with antibiotics. International J. Chem. Studies, 6(2), 2120-2122

Nie, J.; Zhang, M.; Fan, Y.; Wen, Y.; Xiang, B.; Feng, Y.Q. (2005). Biocompatible in-tube solidphase microextraction coupled to HPLC for the determination of angiotensin II receptor antagonists in human plasma and urine. J. Chromatogr. B, 828, 62.

Porwal, P.K.; Talele, G.S. (2017). Development of validated HPLC-UV method for simultaneous determination of metformin, amlodipine, glibenclamide and atorvastatin in human plasma and application to protein binding studies. Bulletin of Faculty of Pharmacy, Cairo University, 55, 129-139.

Radi, A. (2004). Voltammetric study of glibenclamide at carbon paste and sephadex-modified carbon paste electrodes. Anal. Bioanal. Chem., 378, 822-826.

Ramadan, N.K.; Mohamed, H.M.; Mostafa, A.A. (2012). Potentiometric determination of amlodipine besilate and valsartan using microsized and polymeric matrix membrane sensors. Portugaliae Electrochim. Acta., 30(1), 15-29.

Ramos, L.; Bakhtiar, R.; Tse, FL. (2000). Liquid-liquid extraction using 96-well plate format in conjunction with liquid chromatography/tandem mass spectrometry for quantitative determination of methylphenidate (Ritalin) in human plasma. Rapid Commun. Mass. Spectrom., 14(9), 740-745.

Ross, D.P.; Subramanian, S. (1981). Thermodynamics of protein association reactions: forces contributing to stability. Biochem., 20, 3096-3102.

Sulaiman, S.T.; Bader, Z.A. (2009). The voltammetric and thermodynamic behavior of cysteine and its interaction with Albumin. Raf. J. Sci., 20(3), 61-78.

Sulaiman, S.T.; Al-Imam, M.M. (2012). The Binding of sodium nitroprusside with albumin using square wave voltammetry. Raf. J. Sci., 23(2), 42-52.

Tatar, S.; Saglik, S. (2002). Comparison of UV- and second derivative-spectrophotometric and LC methods for the determination of valsartan in pharmaceutical formulation. J. Pharm. Biomed. Anal., 30, 371.

Yan, J.; Wang, W.; Chen, L.; Chen, S. (2008). Electrochemical behavior of valsartan and its determination in capsules. Colloids and Surfaces B, 67, 205-209. 